THE POLITICS OF ART 
Stanford Studies in Middle Eastern and Islamic Societies and Cultures 


\section{THE POLITICS OF ART}

Dissent and Cultural Diplomacy

in Lebanon, Palestine, and Jordan

\section{Hanan Toukan}


STANFORD UNIVERSITY PRESS

Stanford, California

(C2021 by the Board of Trustees of the Leland Stanford Junior University. All rights reserved.

No part of this book may be reproduced or transmitted in any form or by any means,

electronic or mechanical, including photocopying and recording, or in any information

storage or retrieval system without the prior written permission of Stanford University Press.

Printed in the United States of America on acid-free, archival-quality paper

Library of Congress Cataloging-in-Publication Data

Names: Toukan, Hanan, author.

Title: The politics of art : dissent and cultural diplomacy in Lebanon, Palestine, and Jordan / Hanan Toukan.

Other titles: Stanford studies in Middle Eastern and Islamic societies and cultures.

Description: Stanford, California : Stanford University Press, 2021.| Series: Stanford studies in Middle Eastern and Islamic societies and cultures | Includes bibliographical references and index.

Identifiers: LCCN 2020044892 (print) | LCCN 2020044893 (ebook) | ISBN 9781503604346 (cloth) | ISBN 9781503627758 (paperback) | ISBN 9781503627765 (ebook)

Subjects: LCSH: Art—Political aspects—Lebanon. | Art—Political aspects—Palestine. |

Art—Political aspects—Jordan. |Art—Political aspects—Middle East. | Art, Middle Eastern-Finance-International cooperation.

Classification: LCC N72.P6 T68 2021 (print) | LCC N72.P6 (ebook) | DDC 700.956-dc23

LC record available at https://lccn.loc.gov/2020044892

LC ebook record available at https://lccn.loc.gov/2020044893

Cover design: Kevin Barrett Kane

Cover image: Still image from “Motionless Weight.” Ramzi Hazboun and Dia’ Azzeh, 2009.

Typeset by Kevin Barrett Kane in 10.5/14.4 Brill 
For Ala a and Randa 
This page intentionally left blank 